\title{
Long-term integrated soil fertility management in South-western Nigeria: Crop performance and impact on the soil fertility status
}

\author{
B. Vanlauwe ${ }^{1,4}$, J. Diels $^{2}$, N. Sanginga ${ }^{1} \&$ R. Merckx $^{3}$ \\ ${ }^{1}$ Tropical Soil Biology and Fertility Institute of CIAT, PO Box 30677, Nairobi, Kenya. ${ }^{2}$ International \\ Institute of Tropical Agriculture, Ibadan, Nigeria, c/o L.W. Lambourn \& Co., 26 Dingwall Road, Croydon \\ CR9 3EE, England. ${ }^{3}$ Laboratory of Soil and Water Management, Department of Land Management, K.U. \\ Leuven, Kasteelpark Arenberg 20, 3001 Heverlee, Belgium. ${ }^{4}$ Corresponding author*
}

Received 9 July 2004. Accepted in revised form 4 January 2005

Key words: added benefits, alley cropping, Leucaena leucocephala, maize, nitrogen use efficiency, Senna siamea

\begin{abstract}
Crop response, tree biomass production and changes in soil fertility characteristics were monitored in a long-term (1986-2002) alley-cropping trial in Ibadan, Nigeria. The systems included two alley cropping systems with Leucaena leucocephala and Senna siamea on the one hand and a control (no-trees) system on the other hand, all cropped annually with a maize-cowpea rotation. All systems had a plus and minus fertilizer treatment. Over the years, the annual biomass return through tree prunings declined steadily, but more drastically for Leucaena than for Senna. In 2002, the nitrogen contribution from Leucaena residues stabilized at about $200 \mathrm{~kg} \mathrm{~N} / \mathrm{ha} / \mathrm{year}$, while the corresponding value for Senna was about $160 \mathrm{~kg} \mathrm{~N} / \mathrm{ha} /$ year. On average, the four Leucaena prunings were more equal in biomass as well as in amounts of N, P and cations, while the first Senna pruning was always contributing up to $60 \%$ of the annual biomass or nutrient return. Maize crop yields declined steadily in all treatments, but the least so in the Senna + fertilizer treatment where in 2002 still 2.2 tonnes/ha of maize were obtained. Nitrogen fertilizer use efficiency was usually higher in the Senna treatment compared to the control or the Leucaena treatment. Added benefits due to the combined use of fertilizer $\mathrm{N}$ and organic matter additions were observed only for the Senna treatment and only in the last 6 years. At all other times, they remained absent or were even negative in the Leucaena treatments for the first 3 years. Most chemical soil fertility parameters decreased in all the treatments, but less so in the alley cropping systems. The presence of trees had a positive effect on remaining carbon stocks, while they were reduced compared to the 1986 data. Trees had a positive effect on the maintenance of exchangeable cations in the top soil. Exchangeable $\mathrm{Ca}, \mathrm{Mg}$ and $\mathrm{K}-$ and hence ECEC - were only slightly reduced after 16 years of cropping in the tree-based systems, and even increased in the Senna treatments. In the control treatments, values for all these parameters reduced to $50 \%$ or less of the original values after 16 years. All the above points to the Senna-based alley system with fertilizers as the more resilient one. This is reflected in all soil fertility parameters, in added benefits due to the combined use of fertilizer nitrogen and organic residue application and in a more stable maize yield over the years, averaging 2.8 tonnes/ha with maximal deviations from the average not exceeding $21 \%$.
\end{abstract}

\section{Introduction}

* FAX No: +254-2-524763.

E-mail: b.vanlauwe@cgiar.org
A considerable number of long-term experiments have been conducted in Sub-Saharan Africa since 
the 1920s, and have given valuable insights in soil processes and management practices that control soil fertility (Greenland, 1994; Juo et al. 1996; Padwick, 1983; Pieri, 1992). The questions addressed in these trials have shifted with time, and reflect the changes in the research questions arising and the technologies being developed. Models are now increasingly used to evaluate the long-term impact of specific soil fertility replenishment strategies (Giller et al., 1997; Parton et al., 1994), but comprehensive datasets are needed to evaluate the performance of these models. The complexity of agroforestry technologies advocated from the 1980s onwards led to a list of biophysical hypotheses about the functioning and sustainability of these complex systems (Sanchez, 1995), some of which hypotheses may only be tested in long-term trials.

Alley cropping was one of the first promising technologies dealing with soil fertility replenishment that was developed and tested at the International Institute of Tropical Agriculture (IITA) during the eighties and early nineties. In such cropping system, food crops are grown between hedges of preferably $\mathrm{N}_{2}$ fixing trees (Kang et al., 1985). These are regularly cut back to minimize tree-crop competition for water, nutrients, and light. Although it was shown that maize yields in alley cropping systems were better than maize yields in no-tree control treatments, it was acknowledged already at an early stage that addition of chemical fertilizer boosted maize yields further (Kang et al., 1990). Siaw et al. (1991) reported increases in maize production in alley cropping systems after application of $\mathrm{N}$ fertilizer, although alley cropping without fertilizer application already doubled maize yields relative to the no-tree control. From alley cropping trials in Benin Republic on Ultisols with low nutrient status in the topsoil, Akonde et al. (1996) concluded that the greatest monetary output was achieved by fertilizer application. Moreover, Schroth et al. (1995) stated that in view of the unbalanced nutrient composition of leguminous mulches in comparison with crop demand, it seems unlikely that fertilizer application can be avoided in continuous agroforestry associations. Notwithstanding the current controversy on whether alley cropping is adoptable by the small-scale farmer community, recent surveys have shown that crop-tree intercropping systems have been adopted by a significant proportion of the farmers in Benin, Nigeria, and Cameroon, but in a modified form (Adesina et al., 1999).

In 1986, a long-term alley cropping trial with Leucaena leucocephala and Senna siamea as hedgerow species was established at the IITA campus in Ibadan to study the long-term crop and tree performance and soil fertility characteristics with and without the input of chemical fertilizer. The cropping system was a maize (first season) - cowpea (second season) rotation. Major conclusions drawn from the first years of the trial (1986-1990) were: (i) Leucaena produced most biomass and $20 \%$ of the applied $\mathrm{N}$ was used by the maize crop, (ii) maize yields were maintained in alley cropping, but the highest yields were obtained in the Senna system with fertilizer application, and (iii) the level of the major soil nutrients declined in the no-tree controls, but less so in the alley cropping systems (Van der Meersch et al., 1993).

The current paper describes data on biomass and nutrient accumulation of the hedgerows, maize and cowpea yields, and soil fertility characteristics for the following 12 years (1991-2002). The objectives are (i) to evaluate the long-term biomass production and nutrient accumulation of two different trees (a nitrogen fixing one vs. a non-fixing one) planted as hedgerows and as affected by fertilizer addition, the latter to evaluate their assumed 'safety-net' function, (ii) to evaluate the long-term production and stability of crop yields as affected by fertilizer addition and test the hypothesis of improved fertilizer $\mathrm{N}$ use efficiency (NUE) when combined with organic amendments of different quality, and (iii) to assess the impact of long-term application of prunings with or without fertilizer on selected soil fertility characteristics. In an associated report, delta- ${ }^{13} \mathrm{C}$ data obtained in this trial were used to evaluate the Rothamsted C model (Diels et al. 2004).

\section{Materials and methods}

\section{Site description, experimental design, and trial management}

The experiment was conducted at the IITA, Ibadan, Southwestern Nigeria $\left(7^{\circ} 30^{\prime} \mathrm{N}\right.$ and $3^{\circ} 54^{\prime}$ E) on a Ferric Lixisol (FAO 1991) (Table 1) with 


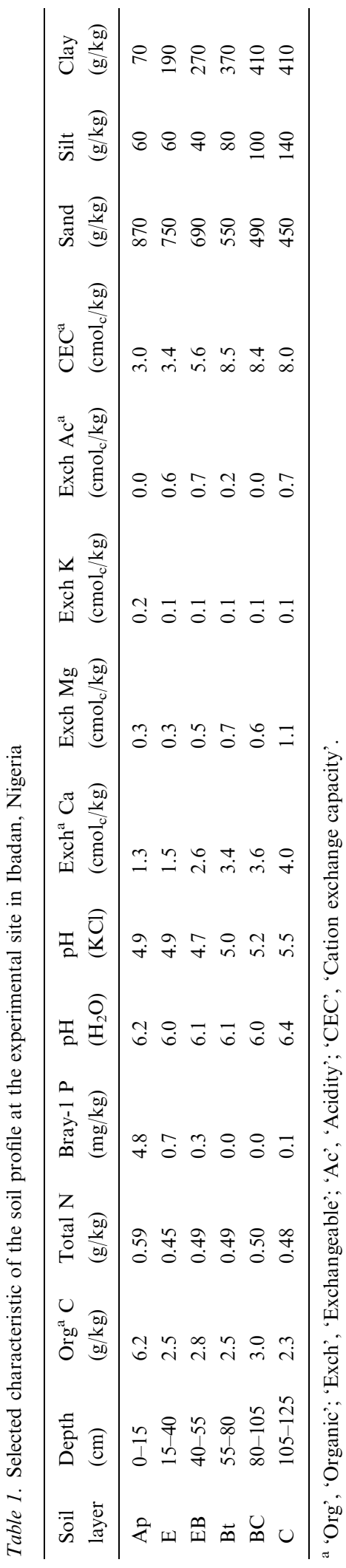

a maximal slope of $5 \%$. A few plots belonging to the lowest replicate are on a Dystric Regosol. Ibadan has a bimodal rainfall pattern (Figure 1). The rainy season starts in March and ends in November, although scanty rainfall occurs until mid-December. The experimental site was established in 1986 as described in detail by Van der Meersch et al. (1993). The trial is a randomized complete block design with 6 treatments and 5 replicates, laid out perpendicular to the slope. The treatments are a no-tree control, alley cropping with $L$. leucocephala, and alley cropping with $S$. siamea, each treated or not with NPK fertilizer. Each alley cropping plot contained 5 hedgerows and 4 alleys, $4.5 \mathrm{~m}$ wide and $10 \mathrm{~m}$ long. L. leucocephala is a fast-growing $\mathrm{N}$-fixing legume tree, whereas $S$. siamea is a non- $\mathrm{N}$-fixing legume tree with less vigorous growth characteristics.

Usually, at the start of the first season (AprilMay) the field was sprayed with herbicide and the hedgerows were pruned a first time. All prunings were applied on the soil surface and the maize was planted at a distance of $0.75 \mathrm{~m}$ between the rows and $0.25 \mathrm{~m}$ within the rows. Between 1991 and 1996, maize variety TZSR-W was used, while during the last 6 years, Oba Super 2 was planted (Table 2). At planting, one third of the $\mathrm{N}$ fertilizer (urea), and the total amount of $\mathrm{P}$ (triple super phosphate) and $\mathrm{K}$ (muriate of potash) fertilizer were broadcast over the complete plot. The yearly fertilizer $\mathrm{N}$ and $\mathrm{P}$ application rates were reduced from 120 to $60 \mathrm{~kg} \mathrm{~N} \mathrm{ha}^{-1}$ and from 90 to $30 \mathrm{~kg} \mathrm{P} \mathrm{ha}^{-1}$ in 1994, while K was continuously applied at $30 \mathrm{~kg} \mathrm{~K} \mathrm{ha}^{-1}$ (Table 2). At about 6 weeks after planting the maize, the hedgerows were pruned a second time. After maize harvest, the field was sprayed with herbicide and the hedgerows were pruned a third time. Cowpea was planted at the same density as the maize and sprayed 3-4 times with insecticides to avoid insect damage to the flowers or pods. The cowpea varieties used each year varied depending on the availability of seeds (Table 2). At about 6 weeks after planting the cowpea crop, the hedgerows were pruned a fourth time. Between 1996 and 1999, only the Leucaena was pruned a fourth time, as the Senna trees did not produce enough biomass to justify a fourth pruning. Usually the field was weeded thrice during the maize season and twice during 


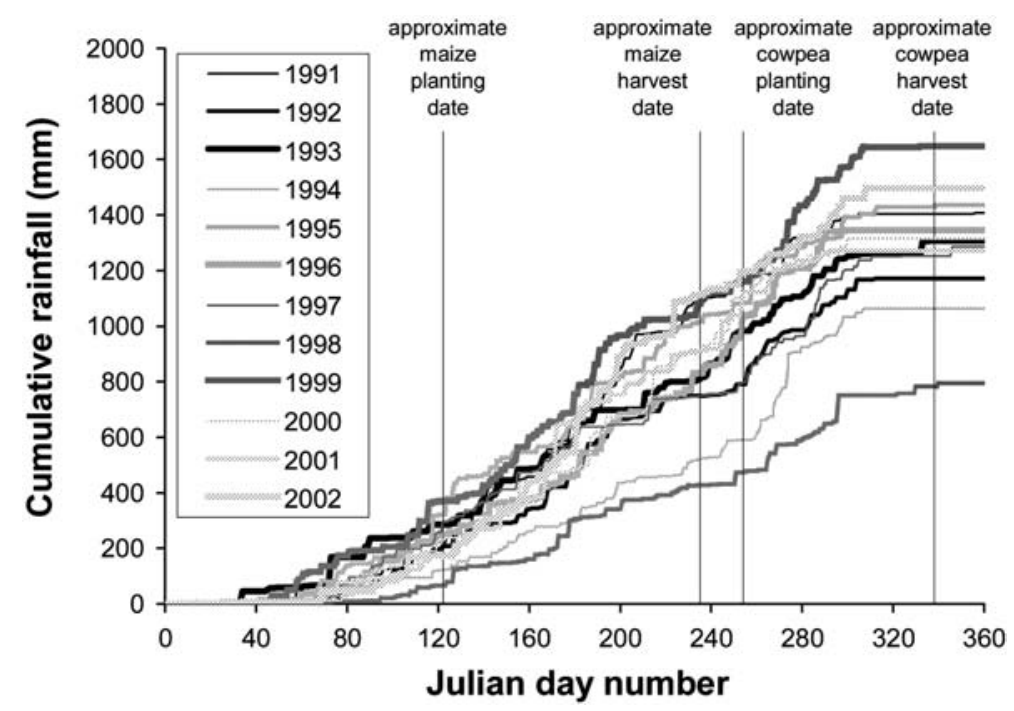

Figure 1. Cumulative rainfall between 1991 and 2002. The vertical bars delineate the approximate maize and cowpea growing seasons.

Table 2. Used maize and cowpea varieties and fertilizer application rates between 1991 and 2002. In 1992, no cowpea was grown, while in 1991 and 1998, the cowpea has failed because of pest and drought problems, respectively.

\begin{tabular}{|c|c|c|c|c|c|}
\hline \multirow[t]{2}{*}{ Year } & \multicolumn{2}{|c|}{ Used varieties } & \multicolumn{3}{|c|}{ Fertilizer application to maize } \\
\hline & Maize & Cowpea & Urea (Kg N/ha) & $\operatorname{TSP}(\mathrm{kg} \mathrm{P} / \mathrm{ha})$ & $\mathrm{KCl}(\mathrm{kg} \mathrm{K} / \mathrm{ha})$ \\
\hline 1991 & TZSR-W & TVX-3236 ${ }^{\mathrm{a}}$ & 120 & 90 & 30 \\
\hline 1992 & TZSR-W & None & 120 & 90 & 30 \\
\hline 1993 & TZSR-W & TVX-3236 & 120 & 90 & 30 \\
\hline 1994 & TZSR-W & IT86D-716 & 60 & 30 & 30 \\
\hline 1995 & TZSR-W & IT86D-1177 & 60 & 30 & 30 \\
\hline 1996 & TZSR-W & TVX-3236 & 60 & 30 & 30 \\
\hline 1997 & Oba Super 2 & Ife Brown & 60 & 30 & 30 \\
\hline 1998 & Oba Super 2 & TVX-3236 ${ }^{\mathrm{a}}$ & 60 & 30 & 30 \\
\hline 1999 & Oba Super 2 & TVX-3236 & 60 & 30 & 30 \\
\hline 2000 & Oba Super 2 & TVX-3236 & 60 & 30 & 30 \\
\hline 2001 & Oba Super 2 & TVX-3236 & 60 & 30 & 30 \\
\hline 2002 & Oba Super 2 & TVX-3236 & 60 & 30 & 30 \\
\hline
\end{tabular}

${ }^{\mathrm{a} C}$ Cowpea crop failed because of pests (1991) or drought (1998).

the cowpea season, of which one weeding takes place immediately before the second and fourth pruning. The number of weedings and prunings and the exact dates of each field activity for each year are presented in Figure 2. Maize and cowpea residues were retained on the plots.

In 1991, the cowpea did not yield any beans due to insect damage. In 1992, the field was left fallow for the second season implying that the trees were only pruned twice and that no cowpea crop was grown. Although in 1998 a cowpea crop was planted, it failed because of lack of rain.

\section{Observations}

At each pruning activity, the total pruning and wood biomass production per hedgerow was 


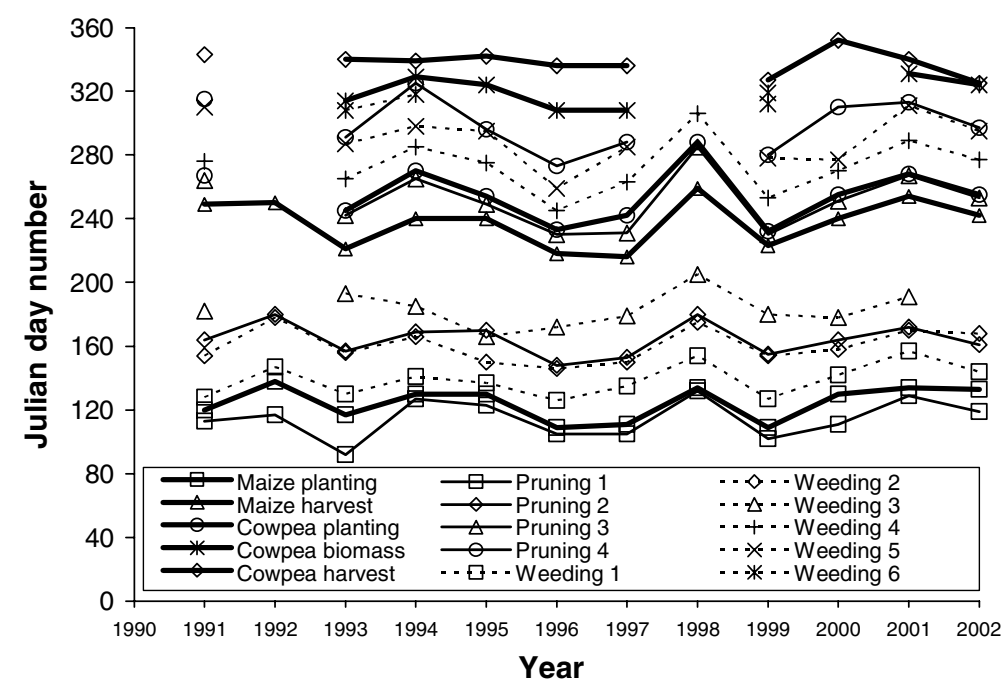

Figure 2. Julian day numbers of the different management activities between 1991 and 2002. In 1992 the second minor season was left fallow while in 1998 the cowpea failed to grow due to drought problems. From 1991 until 1995, both hedgerow species were pruned four times yearly (except in 1992, only twice and in 1998, 3 times). Between 1996 and 2002, the Senna trees were only pruned only during the first three pruning activities.

weighed freshly and subsamples of the prunings were taken to determine the dry matter content. At maize harvest, the total ear and stover fresh weight was measured on the net plot (borders of $1 \mathrm{~m}$ were left on each side of the plots) and a subsample was taken for dry matter determination. In 1992 and 1994, no data on maize stover production are available.

As cowpea tends to lose most of its leafy biomass at harvest, quadrants ( 4.5 by $0.5 \mathrm{~m} ; 2$ quadrants per plot) were used to determine its total aboveground biomass production at physiological maturity. At cowpea harvest, the total pod fresh weight was determined on the net plot and a subsample was taken for dry matter determination.

Before the 2002 season, soil samples were taken at $0-5$ and $5-15 \mathrm{~cm}$ depth, diagonally across the plots ( 24 cores per plot) and bulked per layer.

\section{Chemical analyses}

The maize, cowpea, and hedgerow samples were air-dried and finally oven-dried $\left(65^{\circ} \mathrm{C}\right)$. The maize ear samples were separated into grains and cobs, while the cowpea pod samples were separated into beans and husks. All samples were weighed, ground to pass $0.5 \mathrm{~mm}$, and analysed for total Kjeldahl $\mathrm{N}$. The hedgerow samples were further analysed for total $\mathrm{P}, \mathrm{Ca}, \mathrm{Mg}$, and $\mathrm{K}$ content (IITA, 1982).

The soil samples were analysed for organic $\mathrm{C}$ (Amato, 1983), total Kjeldahl-N, Bray-1 P (IITA, 1982), $\mathrm{pH}\left(\mathrm{H}_{2} 0\right)$ (soil:water ratio of 1:2.5), $\mathrm{pH}$ $(\mathrm{KCl})$ (soil: $\mathrm{KCl}$ solution $1 M$ ratio of $1: 2.5$ ); ECEC(IITA, 1982), and texture (IITA, 1982).

\section{Mathematical and statistical analyses}

The hedgerow biomass and wood production was calculated from the biomass and wood data measured on the 3 central hedgerows. Maize and cowpea yield data in the alley cropping treatments were calculated taking into account the space occupied by the hedgerows.

The apparent fertilizer NUE was calculated as (Eq. 1):

$$
\mathrm{NUE}=\frac{\text { MaizeN }_{\mathrm{F}}-\text { MaizeN }_{0 \mathrm{~F}}}{\mathrm{~N}_{\mathrm{app}}} * 100[\%]
$$

With Maize $\mathrm{N}_{\mathrm{F}}$ and Maize $_{0 \mathrm{~F}}$ the total amount of nitrogen taken up by fertilized and unfertilized maize plants, respectively and $\mathrm{N}_{\text {app }}$ the amount of urea- $\mathrm{N}$ applied. Total $\mathrm{N}$ uptake comprises $\mathrm{N}$ uptake by the grains, cobs, and stover. All units are $\mathrm{kg} \mathrm{N} \mathrm{ha}^{-1}$. Possible added benefits due to a combination of organic treatments and the inorganic fertilizer addition $\left(\mathrm{N}_{\mathrm{add}}\right)$ were calculated as: 


$$
\begin{aligned}
\mathrm{N}_{\mathrm{add}}= & {\left[\mathrm{MaizeN}_{\text {prunF }}-\text { MaizeN }_{\text {prun } 0 \mathrm{~F}}\right] } \\
& -\left[\mathrm{MaizeN}_{\mathrm{contF}}-\text { MaizeN }_{\text {contoF }}\right][\mathrm{kg} \mathrm{N} / \mathrm{ha}]
\end{aligned}
$$

With Maize $\mathrm{N}_{\text {prunF }}$ the amount of nitrogen taken up by the fertilized, residue (Senna or Leucaena) treated maize, Maize $\mathrm{N}_{\text {prunoF }}$ the amount of $\mathrm{N}$ in the corresponding unfertilized stand, Maize $\mathrm{N}_{\text {contF }}$ the amount of nitrogen taken up by the fertilized control maize (no prunings) and Maize $\mathrm{N}_{\text {contoF }}$ the unfertilized control. $\mathrm{N}_{\text {add }}$ so becomes the difference between the extra amount of $\mathrm{N}$ taken up in a residue (Senna or Leucaena) treated, fertilized maize stand and the extra amount of $\mathrm{N}$ taken up in the only inorganically treated maize stand (Vanlauwe et al., 2001a). Vanlauwe et al. (2001b) have been pointing to the possible benefits emanating from the combined use of organic and inorganic sources of $\mathrm{N}$ as an important factor in explaining the improved crop performance sometimes observed under such conditions.

Given the change in $\mathrm{N}$ rate and the change in maize variety (Table 2), we analysed recovery and added benefits emerging from the combined use of organic and inorganic sources of nutrients for three separate categories of data. We grouped together those years where variety TZSR-W was grown with $120 \mathrm{~kg} \mathrm{~N} / \mathrm{ha}$ (years 1991-1993) in a first category, the years where the same variety was grown with $60 \mathrm{~kg} \mathrm{~N} / \mathrm{ha}$ (years 1994-1996) in a second category and finally the years with variety Oba Super 2 and $60 \mathrm{~kg} \mathrm{~N} / \mathrm{ha}$ (years 19972002) in a third category.

The MIXED procedure was used to carry out ANOVA on the obtained plant and soil data (SAS Institute, 1999). For the data on NUE, (Eq. (1)) and added benefits $\left(\mathrm{N}_{\mathrm{add}}\right.$, Eq. (2)), the MIXED procedure was used by category. 'Treatment' was included as fixed variable, while 'Replicate' was included as a random variable. Significant means were separated with the PDIFF option of the LSMEANS statement. Stability analysis (Raun et al., 1993; Guertal et al., 1994) was used to examine the stability of the treatments over time. Treatment means were regressed linearly against annual yields. A mixed model ANOVA was used to test the hypothesis of equality of slopes, using a model similar to one proposed for stability analysis by Stroup et al. (1993). Contrast statements in the ANO-
VA were used for pair wise comparison of slopes.

\section{Results}

Hedgerow biomass production, and $N, P$, and cation content

The evolution over the last 12 years of the trial in dry matter pruning biomass and wood yield are given in Figure 3a and b, respectively. With respect to pruning biomass production (Figure 3a), the large fluctuations between 1992 and 1993 are due to the fact that in 1992 we only pruned twice, with as a consequence a large increase in the biomass of the first pruning of 1993 and hence in the total biomass yield of that year. This effect is especially obvious for Leucae$n a$, less so for the Senna stands. The same trend is logically also present in the wood yield (Figure $3 \mathrm{~b}$ ). The graphs showing the pruning-derived addition of $\mathrm{N}$ (Figure 3c) or P (Figure 3d) are reflecting this abrupt change very well although more clearly for $\mathrm{N}$ than for $\mathrm{P}$. Where the picture for $\mathrm{N}$ is almost a copy of the one for pruning biomass added, the picture for $\mathrm{P}$ shows a more constant return of $\mathrm{P}$ between 7 and $23 \mathrm{~kg} \mathrm{P} / \mathrm{ha}$, less dependent on biomass yield.

As a general trend, over the years between 1991 and 2002, the amounts of biomass returned (and hence $\mathrm{N}$ yield) seem to decline and stabilize at nitrogen additions around $160 \mathrm{~kg} \mathrm{~N} / \mathrm{ha}$ for Senna and around $200 \mathrm{~kg} \mathrm{~N} / \mathrm{ha}$ for Leucaena maintains the largest $\mathrm{N}$ returns, despite the lower biomass yields, compared to Senna. Yet, it has to be acknowledged that the overall decrease over the 12 years was larger for Leucaena than for Senna. The Leucaena systems returned on average between 466 and $512 \mathrm{~kg} \mathrm{~N} / \mathrm{ha}$ in 1991, while these figures were between 239 and 293 for Senna in the same year.

Part of the biomass decline is due to a decreasing number of trees with time. A determination of the number of dead or missing trees in 1999 shows that a large number of the tree rows had more than $25 \%$ of the trees missing (Figure $4 a$ ). This reduction in the number of trees by $25-50 \%$ did not significantly affect the biomass production of the Senna rows, while a similar number of missing trees had a drastic effect on 

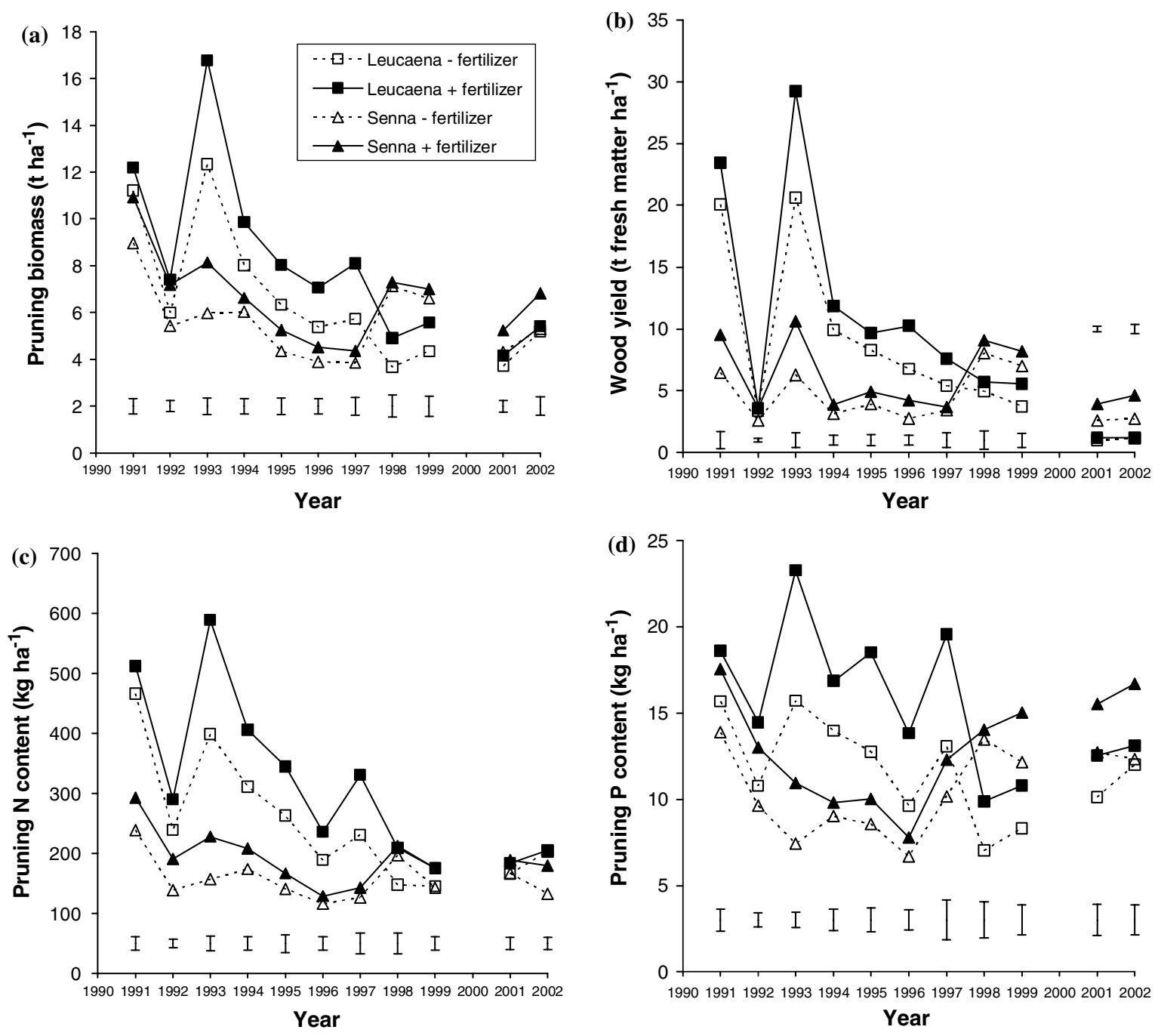

Figure 3. Evolution in pruning biomass added (a), wood yield (b), nitrogen added through prunings (c) and phosphorus added through prunings over 12 years between 1991 and 2002, except for missing data in 2000. Error bars indicate the SED between treatments for each year.

the Leucaena rows where biomass already halved (Figure 4b).

With respect to the changes in quality of the prunings within one year, a few observations can be made. It can be generalized that the first pruning usually has lower concentrations of $\mathrm{N}, \mathrm{P}$ and $\mathrm{K}$ than the following two or three prunings, which is however more than compensated by the larger biomass obtained (Tables 3 and 4). For $\mathrm{Ca}$ and $\mathrm{Mg}$, the opposite holds, there the largest concentrations are found in the first pruning of the Leucaena stands, while for Senna the concentrations of $\mathrm{Ca}$ and $\mathrm{Mg}$ are rather constant over the four prunings. In Table 4 , the combination of changes in nutrient contents and biomass yields allows to calculate the proportional contribution of each pruning to either biomass added or to the addition of each specific nutrient. In general, and for all parameters studied, the first pruning contributes most. However, there are extreme differences for specific parameters between the two species. Senna is clearly different from Leucaena in this that the first pruning always contributes between 50 and $60 \%$ of the total amount added for either biomass or any of the nutrients studied. For Leucaena, these 

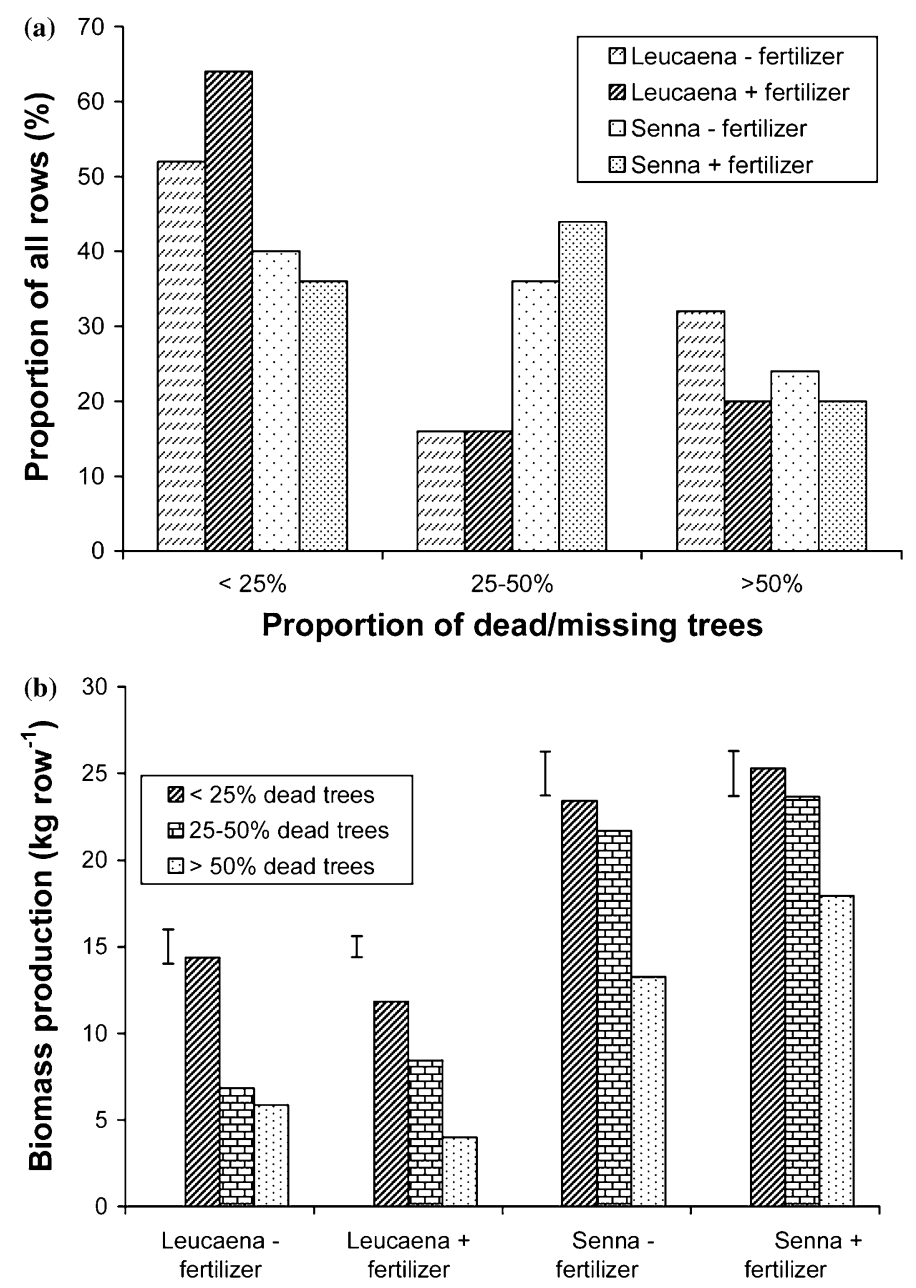

Figure 4. Proportion of dead or missing trees in the two different alley cropping systems as observed in 1999 (a) and its effect on biomass production (b).

contributions are much more equally distributed over the four pruning events, with only a slightly larger (i.e. $30-35 \%$ of the 1 st pruning versus 20 $25 \%$ for the three following ones) contribution from the first pruning.

\section{Selected soil fertility characteristics}

In Table 5 a selection of several important soil characteristics is given, specifically addressing the effects of the different alley cropping treatments and the combined effects of fertilizers. The changes in organic carbon and nitrogen content are discussed more extensively in an accompanying paper (Diels et al., 2004) but it can be restated that the organic carbon in all treatments is decreasing between 1986 and 2002. Yet, this decrease is less dramatic in the treatments with trees due to the sustained inputs of pruning material over the 17 years. As for the 2002 data, differences between all alley cropping treatments and the respective control treatments with or without fertilizer are highly significant and this holds for both soil layers. The $\mathrm{C} / \mathrm{N}$ ratios of all treatments seem doubled compared to the values in 1986, due to the considerable loss in soil nitrogen. Between treatments, only in the top $5 \mathrm{fcm}$ of the control soil without fertilizer is the $\mathrm{C} / \mathrm{N}$ ratio significantly higher than any other treatments.

The changes in Bray-P concentrations are rather more reflecting the fertilizer history of the 
Table 3. Average (averaged over the years 1991-1998) nutrient concentrations of the 4 Leucaena and Senna prunings. Note that not all trees were pruned and all prunings analysed at all pruning events.

\begin{tabular}{|c|c|c|c|c|c|}
\hline & \multicolumn{5}{|c|}{ Concentration } \\
\hline & $\mathrm{N}$ & $\mathrm{P}$ & $\mathrm{Ca}$ & $\mathrm{Mg}$ & $\mathrm{K}$ \\
\hline & \multicolumn{5}{|c|}{$\%$ dry matter } \\
\hline \multicolumn{6}{|c|}{ Leucaena - fertilizer } \\
\hline Pruning 1 & 3.76 & 0.178 & 1.54 & 0.40 & 2.14 \\
\hline Pruning 2 & 4.09 & 0.215 & 1.17 & 0.31 & 2.58 \\
\hline Pruning 3 & 3.26 & 0.191 & 1.28 & 0.36 & 2.39 \\
\hline Pruning 4 & 4.15 & 0.218 & 1.12 & 0.33 & 2.39 \\
\hline \multicolumn{6}{|c|}{ Leucaena + fertilizer } \\
\hline Pruning 1 & 3.74 & 0.189 & 1.60 & 0.41 & 2.13 \\
\hline Pruning 2 & 4.14 & 0.234 & 1.15 & 0.30 & 2.48 \\
\hline Pruning 3 & 3.72 & 0.202 & 1.40 & 0.37 & 2.31 \\
\hline Pruning 4 & 4.24 & 0.231 & 1.16 & 0.33 & 2.41 \\
\hline \multicolumn{6}{|l|}{ Senna - fertilizer } \\
\hline Pruning 1 & 2.62 & 0.179 & 1.76 & 0.25 & 1.41 \\
\hline Pruning 2 & 3.25 & 0.250 & 1.64 & 0.20 & 1.95 \\
\hline Pruning 3 & 3.18 & 0.218 & 1.78 & 0.19 & 1.78 \\
\hline Pruning 4 & 3.50 & 0.184 & 1.62 & 0.21 & 1.92 \\
\hline \multicolumn{6}{|c|}{ Senna + fertilizer } \\
\hline Pruning 1 & 2.72 & 0.190 & 1.76 & 0.22 & 1.40 \\
\hline Pruning 2 & 3.31 & 0.247 & 1.62 & 0.20 & 1.96 \\
\hline Pruning 3 & 3.26 & 0.224 & 1.79 & 0.19 & 1.67 \\
\hline Pruning 4 & 3.44 & 0.178 & 1.66 & 0.21 & 1.87 \\
\hline Minimal SED ${ }^{\mathrm{a}}$ & 0.11 & 0.014 & 0.08 & 0.01 & 0.08 \\
\hline Maximal SED & 0.18 & 0.021 & 0.11 & 0.02 & 0.10 \\
\hline
\end{tabular}

a'SED', 'Standard Error of the Difference'; minimal and maximal SED's are given because each mean comparison test had a different SED depending on the degrees of freedom of both means.

plots than an effect of the trees. Treatments with fertilizer added had, as expected, higher Bray-P concentrations than those without and in both soil layers. Testing for differences between alley treatments with fertilizer and the fertilized control proved significant, but only in the top layer, while the unfertilized alley treatments had similar Bray-P values than the unfertilized controls in both layers.

Soil $\mathrm{pH}$ reflected the treatments but more convincingly in the deeper layer than in the top layer. Alley treatments resulted in on average about $0.5 \mathrm{pH}$ units higher $\mathrm{pH}$ values in the 5$15 \mathrm{~cm}$ layers compared to the control soils, both for $\mathrm{pH}_{\mathrm{H}_{2} \mathrm{O}}$ and $\mathrm{pH}_{\mathrm{KCl}}$. These differences were not significant in the top soil $(0-5 \mathrm{~cm})$ for $\mathrm{pH}_{\mathrm{H}_{2} \mathrm{O}}$ and slightly higher for $\mathrm{pH}_{\mathrm{KCl}}$ in the alley systems. In both layers the effect of fertilizer additions was significant and resulting in a decrease with $0.2-$ $0.3 \mathrm{pH}$ units as compared to the unfertilized treatments.

Cation $(\mathrm{Ca}, \mathrm{Mg}$ and $\mathrm{K})$ concentrations showed very significant responses to the alley treatments. For both depths and all three cations, alley treatments resulted in larger remaining stocks of these nutrients in soil after 17 years. This effect is especially obvious for $\mathrm{Ca}$ and more specifically in the Senna treatments. Testing for differences between the treatments with and those without fertilizers were negative for all the three nutrients and both depths.

While there is no significant change in exchangeable acidity with the treatments, the differences in exchangeable cations in the alley treatments lead to higher ECEC values compared to the control soils and for both layers. Differences in texture were hardly ever significant.

\section{Maize and cowpea grain and stover yield and maize $N$ uptake}

Maize yields have been declining over the years, in an extreme case - the control treatment without fertilizers - even hitting a mere $44 \mathrm{~kg} / \mathrm{ha}$ in 2002 (Figure 5). Yields were sustained best in the Senna + fertilizer treatment with a yield in 2002 of still about 2.2 tonnes of maize per ha. Nevertheless, these remain considerably lower than the initial yield of 3.7 tonnes obtained in 1986 or the peak yield in 1995 of 3.9 tonnes. Yields obtained in the Leucaena treatments with or without fertilizer or in the Senna treatment without fertilizer varied between 0.7 and 1.3 tonnes per ha. Fertilizers only could not sustain yields, the final yield obtained after 16 years of continuous cropping was only 0.4 tonnes per ha.

The yields in the controls with/without fertilizer are very low, but refer to a situation obtained after 17 years of continuous cropping; a situation rather remote from common practice in the region. Usually, farmers fallow their land after some time, but certainly long before 17 years. A comparable long-term trial in the same eco-region of Nigeria by (Juo et al., 1996), however sustained maize yields after 15 years of cropping at 3 tonnes per ha. However, an important difference between their and our experiment is the fertilizer addition rate. Where we only 
Table 4. Proportion of the total annual dry matter or nutrient accumulation in the different prunings. Only years where all treatments had 4 prunings (1991, 1994, and 1995) were included in the analysis. Prunings in 1993 were also excluded as the trees were pruned only twice in 1992.

\begin{tabular}{|c|c|c|c|c|}
\hline & \multicolumn{4}{|c|}{ Proportion of dry matter or nutrient accumulation } \\
\hline & Pruning $1 \%$ & Pruning $2 \%$ & Pruning 3\% & Pruning $4 \%$ \\
\hline \multicolumn{5}{|l|}{ Total dry matter } \\
\hline Leucaena - fertilizer & 30.7 & 21.7 & 25.8 & 22.6 \\
\hline Leucaena + fertilizer & 30.2 & 21.2 & 27.1 & 22.0 \\
\hline Senna - fertilizer & 55.6 & 16.4 & 17.4 & 10.9 \\
\hline Senna + fertilizer & 59.5 & 15.0 & 15.7 & 10.0 \\
\hline $\mathrm{SED}^{\mathrm{a}}$ & 2.0 & 0.9 & 1.6 & 1.0 \\
\hline \multicolumn{5}{|l|}{ Total $\mathrm{N}$ uptake } \\
\hline Leucaena - fertilizer & 28.5 & 22.3 & 25.0 & 25.2 \\
\hline Leucaena + fertilizer & 28.2 & 21.6 & 25.5 & 25.6 \\
\hline Senna - fertilizer & 50.0 & 17.8 & 19.0 & 13.6 \\
\hline Senna + fertilizer & 54.8 & 16.5 & 17.4 & 11.2 \\
\hline SED & 2.3 & 0.9 & 1.9 & 1.3 \\
\hline \multicolumn{5}{|l|}{ Total P uptake } \\
\hline Leucaena - fertilizer & 29.4 & 23.9 & 22.6 & 24.4 \\
\hline Leucaena + fertilizer & 28.7 & 23.5 & 23.0 & 24.6 \\
\hline Senna - fertilizer & 49.6 & 19.1 & 17.9 & 12.6 \\
\hline Senna + fertilizer & 55.3 & 17.8 & 15.4 & 10.8 \\
\hline SED & 1.3 & 1.4 & 1.7 & 1.1 \\
\hline \multicolumn{5}{|l|}{ Total Ca uptake } \\
\hline Leucaena - fertilizer & 35.5 & 21.2 & 24.3 & 20.2 \\
\hline Leucaena + fertilizer & 34.7 & 19.9 & 28.2 & 17.4 \\
\hline Senna - fertilizer & 54.1 & 15.8 & 19.4 & 11.3 \\
\hline Senna + fertilizer & 59.0 & 13.7 & 17.4 & 10.6 \\
\hline SED & 2.5 & 1.5 & 2.3 & 1.1 \\
\hline \multicolumn{5}{|l|}{ Total Mg uptake } \\
\hline Leucaena - fertilizer & 34.6 & 18.6 & 25.5 & 22.4 \\
\hline Leucaena + fertilizer & 35.6 & 17.5 & 28.1 & 19.6 \\
\hline Senna - fertilizer & 61.8 & 14.0 & 14.3 & 10.6 \\
\hline Senna + fertilizer & 62.2 & 14.5 & 13.5 & 10.2 \\
\hline SED & 3.2 & 1.3 & 2.0 & 1.3 \\
\hline \multicolumn{5}{|l|}{ Total K uptake } \\
\hline Leucaena - fertilizer & 28.8 & 24.6 & 25.9 & 21.4 \\
\hline Leucaena + fertilizer & 28.8 & 23.2 & 27.5 & 20.2 \\
\hline Senna - fertilizer & 48.4 & 20.5 & 18.1 & 12.9 \\
\hline Senna + fertilizer & 54.5 & 18.6 & 15.3 & 11.8 \\
\hline SED & 1.6 & 1.4 & 1.4 & 0.9 \\
\hline
\end{tabular}

aSED, 'Standard Error of the Difference'.

applied N-rates of $60 \mathrm{~kg} \mathrm{~N} / \mathrm{ha}$ in the last 9 years, they used a $\mathrm{N}$ addition rate of minimally $120 \mathrm{~kg} \mathrm{~N} / \mathrm{ha}$.

Stability analysis is a standard tool to evaluate long-term trends in yields (Guertal et al., 1994; Raun et al., 1993). The stability analysis indicated clear differences among the treatments in yield stability over time: the hypothesis of equality of slopes was rejected by the F-test $(P=0.0007)$. A plot of treatment means vs. annual production means (Figure 6), revealed that the Senna + fertilizer treatment not only sustains the highest average yield as discussed earlier, but also ensures the largest stability (lowest slope, i.e. 0.747). The slope of this treatment was significantly different from the control 


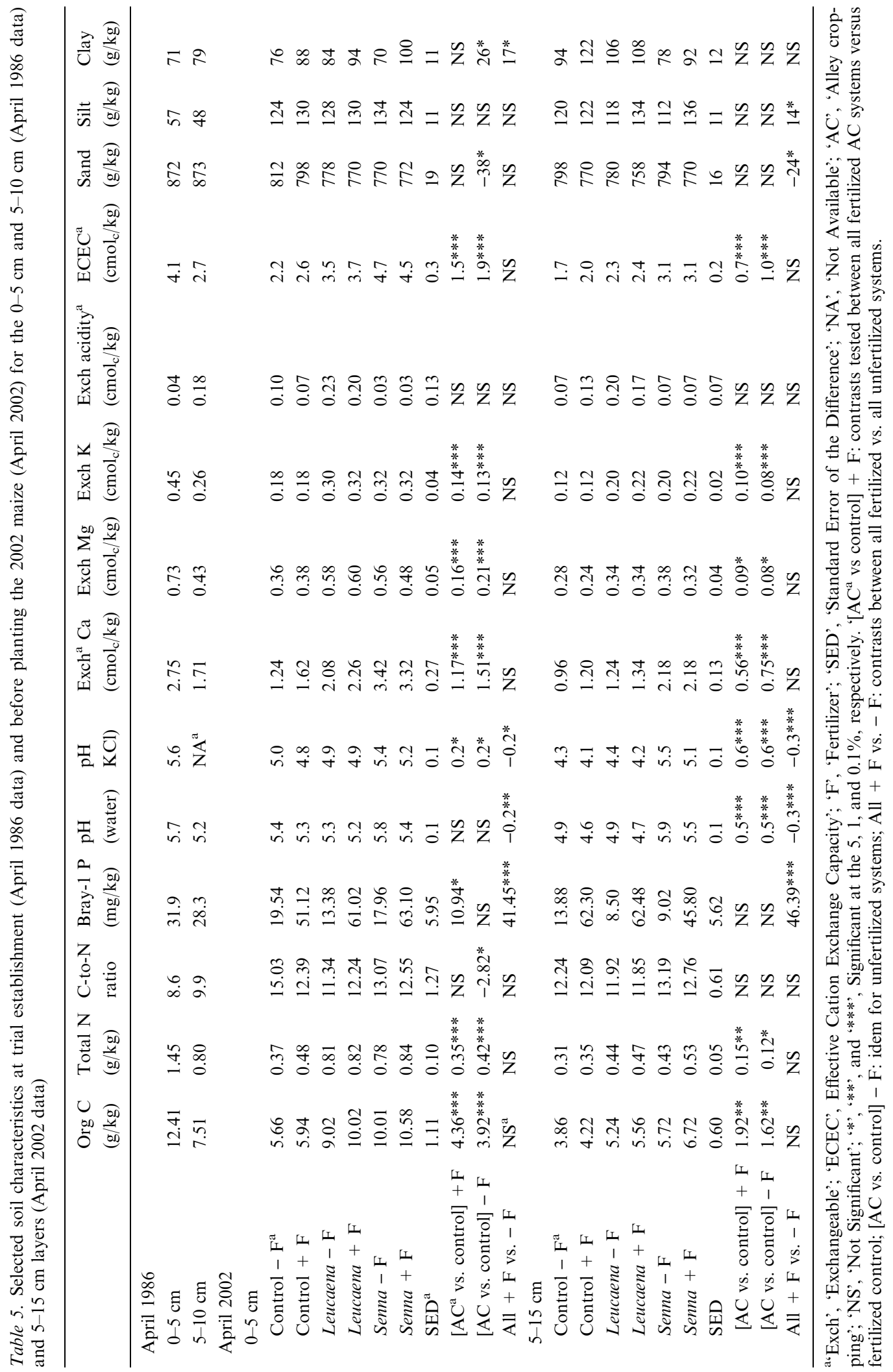




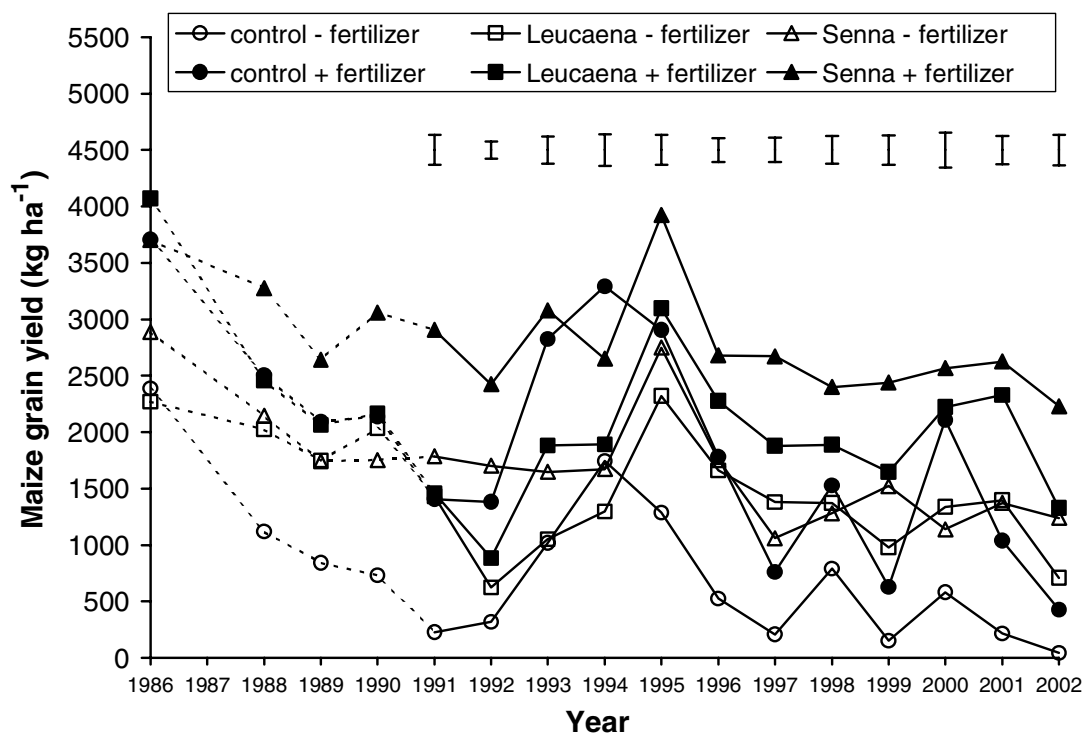

Figure 5. Maize grain yields obtained in the different treatments since the start of the trial in 1986 and up to 2002. Error bars are given from 1992 onwards indicating the SED between treatments for each separate year.

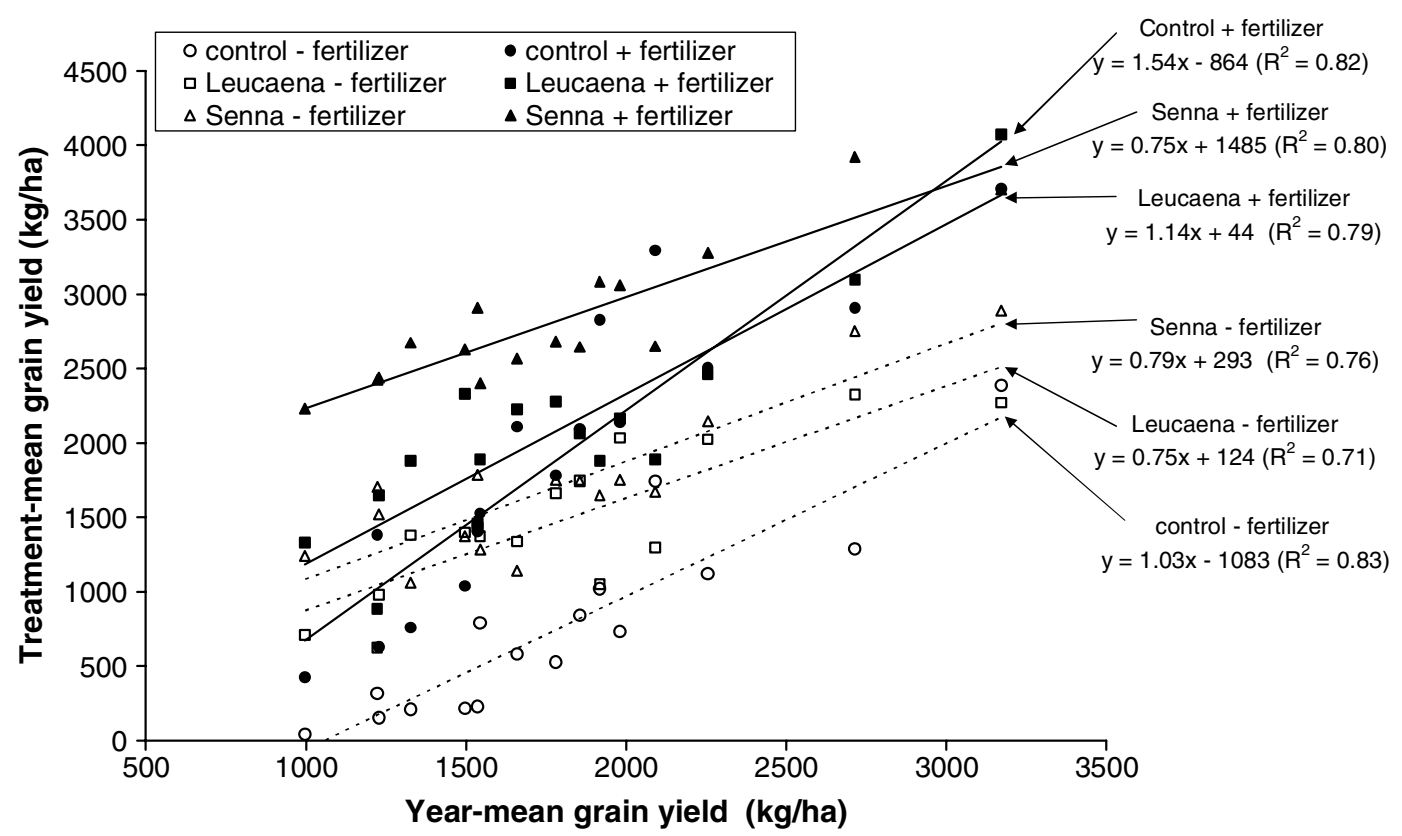

Figure 6. Maize yield stability analysis over the entire duration of the experiment: treatment means vs. year means of maize grain yield.

(maize) with fertilizer $\left(P=0.0002\right.$ for $\mathrm{H}_{0}$ : equal slopes) and from Leucaena with fertilizer $(P=0.052)$. The slope of the Senna + fertilizer treatment (0.747) was almost equal to and not statistically different from the slopes of the Leucaena without fertilizer (0.752) and the Senna 


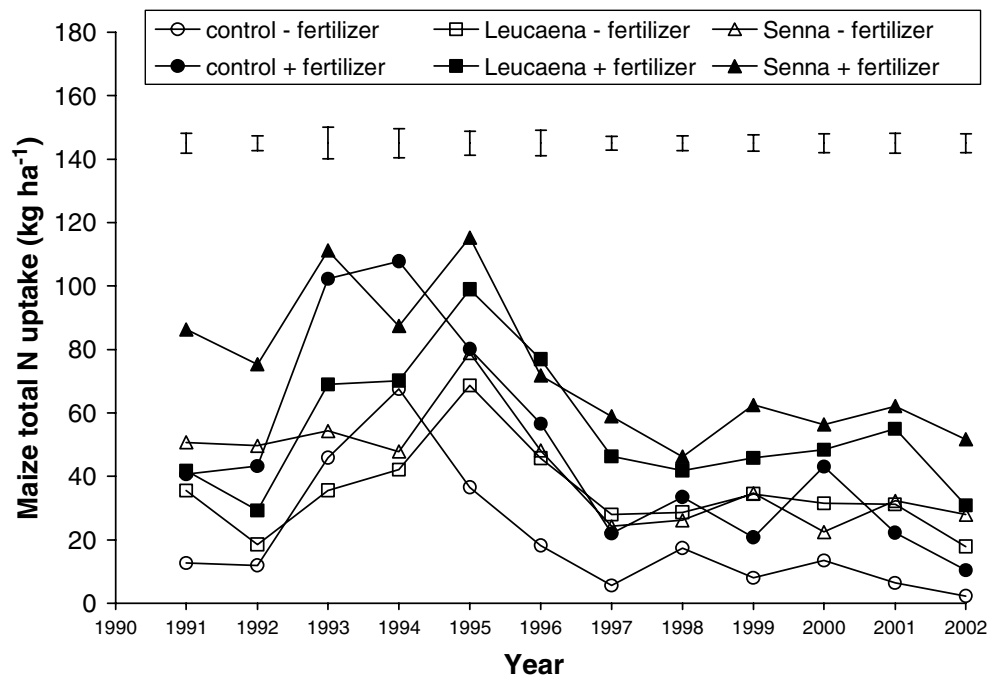

Figure 7. Maize total N uptake in the different treatments between 1991 and 2002 for the different treatments. Error bars indicate the SED between treatments for each individual year.

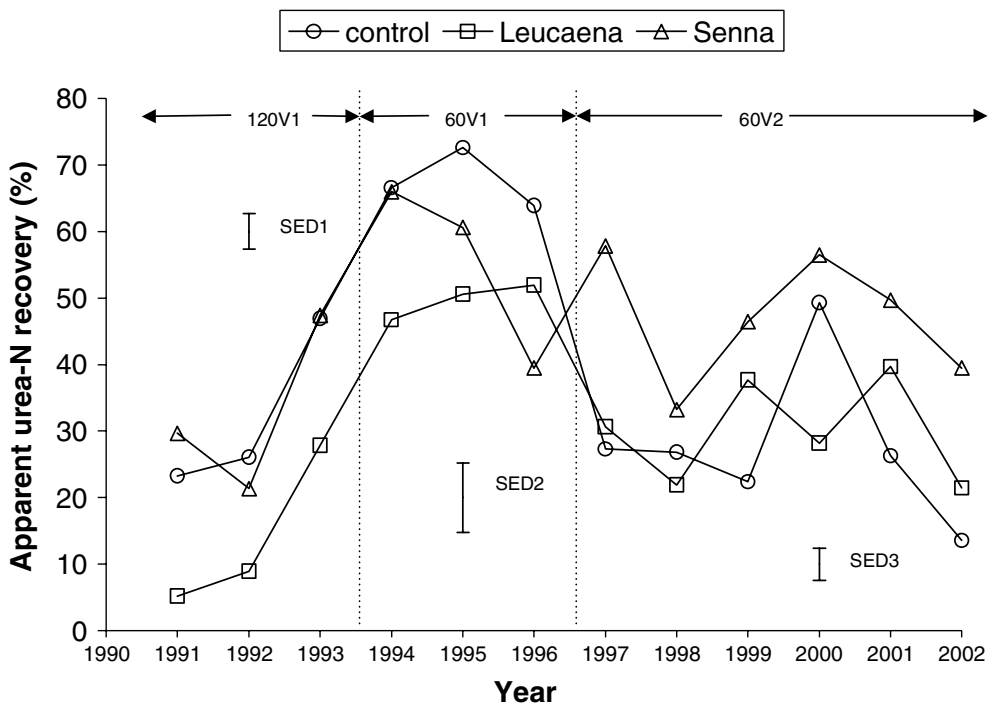

Figure 8. Apparent nitrogen use efficiency (\%) by maize in the different treatments between 1991 and 2002 for the different treatments. The error bars indicate the respective SED's between treatments for each category. 120V1 combines years 1991-1993 where maize variety TZSR-W is used with $120 \mathrm{~kg} \mathrm{~N} / \mathrm{ha}$ (SED1); 60V1 groups years 1994-1996 where variety TZSR-W is used with $60 \mathrm{~kg} \mathrm{~N} / \mathrm{ha}$ (SED2) and 60V2 groups years 1997-2002 where variety Oba Super 2 is grown with $60 \mathrm{~kg} \mathrm{~N} / \mathrm{ha}$ (SED3).

without fertilizer (0.791) treatments. While those three can thus be termed stable, only the Sen$n a+$ fertilizer also produces an acceptable yield.

Maize nitrogen uptake is given in Figure 7. The data reflect the change in fertilizer addition rate that reduced the $\mathrm{N}$ rate from 120 to $60 \mathrm{~kg} \mathrm{~N} /$ ha from 1994 onwards. Between 1991 and 1993, nitrogen uptake increased, remained more or less constant in 1994 and started to decline steadily down to 2002. In general, this mirrors the picture obtained with the maize yields. Largest amounts of N taken up are obtained in the Senna + fertilizer system, the lowest ones logically in the control, unfertilized maize.

The apparent fertilizer NUE data are given in Figure 8. First, we acknowledge that the calcu- 
Table 6. Apparent NUE and Nadd values for three categories of maize N uptake 120V1, Maize variety TZSR-W with 120 kg N/ ha; 60V1, Maize variety TZSR-W with $60 \mathrm{~kg} \mathrm{~N} / \mathrm{ha} ; 60 \mathrm{~V} 2$, Maize variety Oba Super 2 with $60 \mathrm{~kg}$ N/ha. NUE, nitrogen use efficiency, cf. Eq. (1). Nadd, nitrogen added benefit, cf. Eq. (2)

\begin{tabular}{|c|c|c|c|}
\hline \multirow[b]{2}{*}{ Treatment } & \multicolumn{3}{|c|}{ Category } \\
\hline & $120 \mathrm{~V} 1$ & $60 \mathrm{~V} 1$ & $60 \mathrm{~V} 2$ \\
\hline & \multicolumn{3}{|c|}{ NUE \% } \\
\hline Control & 32.08 & 67.68 & 27.62 \\
\hline Leucaena & 14.00 & 49.74 & 29.93 \\
\hline Senna & 32.81 & 55.33 & 47.19 \\
\hline \multirow[t]{2}{*}{$\mathrm{SED}^{\mathrm{a}}$} & $5.30 * *$ & $10.38^{\mathrm{NS}}$ & $4.84 * * *$ \\
\hline & \multicolumn{3}{|c|}{ Nadd $[\mathrm{kg} \mathrm{N} / \mathrm{ha}]$} \\
\hline Leucaena & -21.70 & -10.76 & 1.39 \\
\hline Senna & 0.86 & -7.41 & 11.74 \\
\hline $\mathrm{SED}^{\mathrm{a}}$ & $5.15^{* * *}$ & $9.94^{\mathrm{NS}}$ & $3.20 * *$ \\
\hline
\end{tabular}

${ }^{a}$ SED, 'Standard Error of the Difference', NS, not significant, ***, ** and * significant at 0,$1 ; 1$ and $5 \%$, respectively.

lated NUE is termed 'apparent' for two reasons. First, it does not refer to the real fertilizer recovery as obtained for instance with labelled N-fertilizer and secondly, the nitrogen fertilizer addition always was accompanied with a dose of $\mathrm{P}$ and $\mathrm{K}$. In principle, the calculated recoveries may as a consequence well include a larger amount of soil $\mathrm{N}$ taken up by the crops due to a more vigorous crop growth with the extra $\mathrm{P}$ and K. While the fertilizer treatments effectively enhanced the concentrations of available $\mathrm{P}$ (Bray-I-P, Table 5), values were always above critical levels (Sanchez, 1976) precluding a Presponse. As for potassium, it can be seen that potassium additions had no significant effect on exchangeable K-levels.

The NUE results show rather low values in 1991 and 1992 (between 5 and 30\% irrespective the treatment), then increasing to maximal values between 46 and $73 \%$ in the years 1994 and 1995 and then slowly decreasing to values between 14 and $40 \%$ in 2002. As explained in the Materials and methods section, the change in fertilizer rate (in 1994) and cultivar (in 1997) necessitated the grouping of data in three categories. The results of the subsequent ANOVA are presented in Table 6. Only for two combinations, $120 \mathrm{~V} 1$ and $60 \mathrm{~V} 2$ a significant treatment effect emerged. The first category $120 \mathrm{~V} 1$, covering the years 19911993 showed extremely low NUE for the Leucaena systems (14\%), and similar NUE values around $32 \%$ for the control and Senna systems.
This adds to the picture that emerged from the total $\mathrm{N}$ uptake (Figure 7) which is lower in the Leucaena systems as compared with the fertilized Senna system. In the 60V1 category, covering the years 1994-1996, no treatment effects on NUE could be found. As from year 1997 onwards, for category $60 \mathrm{~V} 2$, again significant treatment effects on the NUE values were observed. In line with the better sustained yields in the fertilized Senna system, also the highest NUE values were recorded, averaging $47 \%$, compared to 28 or $30 \%$ for the control and Leucaena treatments, respectively.

Analysing for possible added benefits, due to a combination of organic vs. inorganic sources of $\mathrm{N}$, revealed that the treatments had only significant effects for the first and the last period or category of data, where the data are averaged for the three separate periods (Table 6). For 120V1, the first three years of the analysis, a negative effect emerged, showing that (i) no added benefit was obtained with Senna, while (ii) a negative effect was obtained with Leucaena. Introducing Leucaena in the system entailed that the increase in $\mathrm{N}$-uptake by maize due to fertilizer addition decreased with $21.70 \mathrm{~kg} \mathrm{~N} / \mathrm{ha}$. Again, in the category $60 \mathrm{~V} 1$, no significant effects were seen, while in the third period or $60 \mathrm{~V} 2$ category, (i) no added benefit was found for Leucaena, while an added benefit of $11.74 \mathrm{~kg} \mathrm{~N} / \mathrm{ha}$ was found for the Senna systems. 
Cowpea grain yields varied between 117 and $1265 \mathrm{~kg} \mathrm{ha}^{-1}$ with highest yields occurring in 1995 and the lowest yields in 2001 (data not shown). Differences between treatments were usually not significant except in 1995, 1996, and 1999, in which years yields in the Leucaena treatments were lowest. The cowpea crop failed in 1991 and 1998 while in 1992 no cowpea was planted. The total aboveground biomass production at peak biomass varied between 241 and $1536 \mathrm{~kg} \mathrm{ha}^{-1}$ with highest values in 2002 and lowest in 2001 (data not shown).

The underperformance of the N-fixing Leucaena system relative to the Senna system is somehow unexpected. Reasons for this can be found in an enhanced competition between crops and Leucaena trees with consequent inefficient use of $\mathrm{N}$ by the crop and ensuing production limitation. The latter has been the subject of a number of earlier studies where the inefficient use of $\mathrm{N}$ in a Leucaena based agroforestry systems has been the focus. In (Vanlauwe et al., 1996) we pointed to the low recovery of Leucaena derived $\mathrm{N}$ in the maize grains, leaves, stems and cobs totalling 19.4\%. Similar data (Vanlauwe et al., 1998b) showed a low recovery of $\mathrm{N}$ derived from Leucaena residues of $8.6 \%$ in the maize grains, while an effective competition for mineral $\mathrm{N}$ between maize and hedgerows was demonstrated in (Vanlauwe et al., 1998a). A second consideration points to the decrease in net primary productivity (trees + crops) in the Leucaena system towards the end of the trial, which can be attributed to a severe tree die-back. Before, the net primary production has been continuously higher in the Leucaena system, up to a few years before the end of the trial, while the primary productivity was only high in the Senna system in presence of $\mathrm{N}$ fertilizer.

\section{Discussion}

\section{Hedgerow production}

The declining biomass production of the trees in the alley cropping systems provokes questions as to the long-term sustainability of such systems. While the system remains to perform better as far as crop production and soil quality maintenance is concerned, the added value may become too small to make it a rational option. In this study, however, the emphasis was only on monitoring the long-term changes, without providing a complete cost-benefit analysis of the systems involved. One of the reasons of the decline in tree biomass production, apart from the decline in soil fertility, seems to reside in the increasing vulnerability of the trees to the regular pruning as with time, quite large numbers of trees did die (Figure 4a). Again, differences are worth observing between the Senna and Leucaena stands. While a fall-out of $25-50 \%$ of the trees did not significantly affect the biomass production of the Senna rows, the same number of missing trees had a considerable effect on the Leucaena rows (Figure 4b). Apparently, the Senna trees are better competitors to occupy the available aboveground space and close the canopy easily, while Leucaena trees fail to do so. The morphology of both trees account for this, Leucaena displaying a tall growth pattern, Senna having a more widespread canopy.

The drastic shifts in biomass production between 1992 and 1993, as stated earlier due to the omission of the two last prunings in 1992, confirms first of all the more even spread of biomass over the four prunings in Senna, but may also suggest a better performance and continued growth of Leucaena over the dry season 19921993.

\section{Soil characteristics}

It can be concluded that perhaps one of the most interesting features - apart from the more documented changes on soil organic $\mathrm{C}$ and $\mathrm{N}$ - of the alley cropping trials reside in a better conservation of the limited reserves of exchangeable cations like $\mathrm{Ca}, \mathrm{Mg}$ and $\mathrm{K}$ in weathered soils like the one at hand. While this holds for all three nutrients studied here, the effects seem most striking for $\mathrm{Ca}$, more in particular in combination with Senna. This has been discussed in another paper (Vanlauwe et al., 2004) specifically addressing recycling of $\mathrm{Ca}$ in Senna based alley cropping trials. In view of the absence of a fertilizer effect it must be concluded that the higher concentrations in the two soil layers under alley cropping are due to a reduced loss through leaching and a recycling of the captured nutrients through litter and pruning additions. It has often 
been argued that trees in cropping systems serve as a kind of safety-net, preventing crop nutrients to leach beyond the rooting zone. The present results provide evidence for such mechanism, but more so for Senna than for Leucaena. In Vanlauwe et al. (2004), two factors are suggested to explain the difference between the two systems: (i) Senna trees recover more $\mathrm{Ca}$ from the subsoil than Leucaena trees, and (ii) the higher nitrate leaching in the system with $\mathrm{N}$-fixing Leucaena trees compared to with the non-fixing Senna trees, as indicated by a long-term $\mathrm{N}$ balance, might increase the transport of $\mathrm{Ca}$ and other companion cations of nitrate to deeper layers and hence below the rooting zone of the crops.

\section{Grain/biomass}

A general impression that emerges is that the only system that reasonably resists resource degradation while still producing acceptable yields is the Senna + fertilizer system. Soil chemical characteristics, NUE, added benefits from the combination of organics and fertilizers and yields all confirm this. On top of this, farmers are often more interested in yield stability over the years rather than the occasional peak yield, followed by years with low yields or crop failures. From the stability analysis, it can be concluded that only the Senna + fertilizer treatment can be considered to perform at an acceptable level.

\section{Maize N uptake}

The changes in nitrogen fertilizer addition rate in 1994 and the subsequent shift to another maize cultivar in 1997 precluded somehow a straightforward analysis of nitrogen use by maize in the different treatments. However, the re-grouping of the data in sets combining the same cultivar and fertilizer rate reveals an apparent adverse effect of Leucaena trees on nitrogen recovery by maize in the first period (120V1). A recovery as low as $14 \%$ is of concern, together with the related observation that combination of an organic and an inorganic $\mathrm{N}$ source seems to operate in a downward direction. Despite the large supply of $\mathrm{N}$ in these systems, the maize crop does not seem to benefit greatly from it, most likely due to competition with the trees.
After the transition period (60V1), the superior performance of the Senna + fertilizer system emerges, with an average NUE of $47 \%$ and an added benefit in the organic/inorganic treatments valued at an average of $11.74 \mathrm{~kg} \mathrm{~N} / \mathrm{ha}$. In the same period, none of those effects were obtained with the Leucaena system, as both NUE and added benefits were not significantly different from the control.

We suggest that especially the cation recycling characteristics of the Senna trees are responsible for the better performance of this system. The evidence of cation recycling, as also found in other trials with Senna (Vanlauwe et al., 2004), accounts for the larger NUE values obtained as also mineral nitrogen species can be recycled by the deeper capture of the tree roots. The striking difference between Senna and Leucaena as regards the proportion the first pruning takes in terms of nutrients added, confirms that Senna is able to recover large amounts of nutrients outside the maize growing season and prevents them to leach beyond reach of the maize roots with the following rains.

\section{Conclusions}

Comparing the two tree-based cropping systems with Leucaena vs. Senna revealed that, while the former is a nitrogen fixing tree and hence accounts for an extra nitrogen input, the latter provides for a more resilient system. All indicators (soil organic carbon contents and other fertility parameters, maize yields, stability analysis of these yields) underscore this. The main reason for this difference can be ascribed to (i) different rooting patterns of Senna vs. Leucaena, so at the same time being less competitive with maize roots and also recovering nutrients from deeper soil layers (out of reach of maize roots) and/or over the dry period; (ii) to the different qualities of the added pruning material, where slower decomposition seems to be a positive treat, better protecting the soil surface from the impact of rain and temporarily immobilising nutrients so preventing them from leaching beyond the rooting zone and (iii) the tree die-back observed in the Leucaena system, reducing primary production towards the end of the investigated period. The data indicate that while nitrogen remains a 
crucial yield determinant, measures enhancing its use efficiency are often more important than those increasing its inputs. With the present longterm Senna trials, it is shown that maintaining all other soil fertility parameters is crucial in this. Maintaining adequate $\mathrm{Ca}, \mathrm{Mg}, \mathrm{K}$ concentrations, preventing $\mathrm{pH}$ decline and reducing Al-concentrations all fit under such objective but is a far more difficult target to reach when lime or compound fertilizers are not available or out of reach. Selecting trees for soil fertility maintenance therefore should take those issues into account, rather than focusing on nitrogen inputs only.

\section{Acknowledgements}

We are particularly grateful to DGDC, the Belgian Directorate General for Development Cooperation, for their sustained support through several and subsequent collaborative projects between K.U. Leuven and IITA on 'Soil Organic Matter Dynamics' and 'Balanced Nutrient Management Systems for Maize-based Farming systems in the Moist Savanna and Humid Forest Zone of West-Africa', allowing one of the rare and much needed long-term field trials like this. R. Merckx acknowledges support from FWO (Fonds voor Wetenschappelijk Onderzoek, Vlaanderen), IRD (Institut de Recherche pour le Développement) and TSBF-CIAT (The Tropical Soil Biology and Fertility Institute of the 'Centro Internacional de Agricultura Tropical') to support part of this work during his sabbatical at IRD/TSBF-CIAT.

\section{References}

Adesina A A, Coulibaly O, Manyong V M, Sanginga P C, Mbila D, Chianu J and Kamleu D G 1999 Policy Shifts and Adoption of Alley Farming in West and Central Africa, Ibadan, Nigeria. $21 \mathrm{pp}$.

Akonde T P, Leihner D E and Steinmuller N 1996 Alley cropping on an Ultisol in subhumid Benin. Part 1: longterm effect on maize, cassava and tree productivity. Agroforestry Syst. 34, 1-12.

Amato M 1983 Determination of carbon ${ }^{12} \mathrm{C}$ and ${ }^{14} \mathrm{C}$ in plant and soil. Soil Biol Biochem. 15, 611-612.

Diels J, Vanlauwe B, van der Meersch M-K, Sanginga N and Merckx R 2004 Long-term soil organic carbon dynamics in a subhumid tropical climate: ${ }^{13} \mathrm{C}$ data in mixed $\mathrm{C}_{3} / \mathrm{C}_{4}$ crop- ping and modeling with ROTHC. Soil Biol. Biochem. 36, 1739-1750.

FAO 1991 World Soil Resources: An Explanatory Note on the FAO World Soil Resources Map at 1:25,000,000 Scale. Food and Agriculture Organisation of the United Nations, Rome, Italy. 58 pp.

Giller K E, Cadisch G, Ehaliotis C, Adams E, Sakala W D and Mafongoya P L 1997 Building soil nitrogen capital in Africa. In Replenishing Soil Fertility in Africa. Eds. R J Buresh, P A Sanchez and F Calhoun. pp. 151-192. SSSA, ASA, Wadington.

Greenland D J 1994 Long-term cropping experiments in developing countries: the need, the history and the future. In Long-term Experiments in Agricultural and Ecological Sciences. Proceedings of a Conference to Celebrate the 150th Anniversary of Rothamsted Experimental Station, Rothamsted, UK, 14-17 July, 1993. Eds. R A Leigh and A E Johnston. pp. 187-209. CAB International, Wallingford, Oxon, UK.

Guertal E A, Raun W R, Westerman R L and Boman R K 1994 Applications of stability analysis for single-site, longterm experiments. Agron. J. 86, 1016-1019.

IITA 1982 Automated and Semi-automated Methods for Soil and Plant Analysis. International Institute of Tropical Agriculture, Ibadan, Nigeria.

Juo A S R, Franzluebbers K, Dabiri A and Ikhile B 1996 Soil Properties and Crop Performance on a Kaolinitic Alfisol After 15 Years of Fallow and Continuous Cultivation. Plant and Soil 180, 209-217.

Kang B T, Grimme H and Lawson T L 1985 Alley cropping sequentially cropped maize and cowpea with leucaena on a sandy soil in Southern Nigeria. Plant Soil 85, 267-277.

Kang B T, Reynolds L and Atta Krah A N 1990 Alley farming. Adv. Agron. 43, 315-359.

Padwick G W 1983 Fifty years of Experimental Agriculture II. The maintenance of soil fertility in tropical Africa: a review. Exp. Agric. 19, 293-310.

Parton W J, Woomer P L and Martin A 1994 Modelling soil organic matter dynamics and plant productivity in tropical ecosystems. In The Biological Management of Tropical Soil Fertility. Eds. P L Woomer and M J Swift. pp. 171-188. John Wiley and Sons, Chichester, UK.

Pieri C J M G 1992 Fertility of Soils: A Future for Farming in the West African Savannah. Springer-Verlag, New York, USA. 548 pp.

Raun W R, Barreto H J and Westerman R L 1993 Use of stability analysis for long-term soil fertility experiments. Agron. J. 85, 159-167.

Sanchez P A 1976 Properties and Management of Soils in the Tropics. John Wiley and Sons, New York, USA. 618 pp.

Sanchez P A 1995 Science in agroforestry. Agroforest. Syst. 30, 5-55.

SAS Institute, 1999. SAS OnlineDoc ${ }^{\circledR}$, Version 8. SAS Institute Inc., Cary, NC, USA.

Schroth G, Oliver R, Balle P, Gnahoua G M, Kanchanakanti N, Leduc B, Mallet B, Peltier R and Zech W 1995 Alley cropping with Gliricidia sepium on a high base status soil following forest clearing: effects on soil conditions, plant nutrition and crop yields. Agroforest. Syst. 32, 261-276.

Siaw D, Kang B T and Okali D U U 1991 Alley cropping with Leucaena leucocephala (Lam.) De Wit and Acioa barteri (Hook. f.) Engl. Agroforest Syst 14, 219-231.

Stroup W W, Hildebrand P E and Francis C A 1993. Farmer participation for more effective research in sustainable 
agriculture. In Technologies for Sustainable Agriculture in the Tropics. Proceedings of Two International Symposia Held in San Antonia, TX and Denver, CO, 1990 and 1991 respectively, ASA Special Publication No.56. American Society of Agronomy (ASA). Eds. J Ragland and R Lal. pp. 153-186. Madison, Wisconsin, USA.

Van der Meersch M K, Merckx R and Mulongoy K 1993 Evolution of plant biomass and nutrient content in relation to soil fertility changes in two alley cropping systems. In Soil Organic Matter Dynamics and the Sustainability of Tropical Agriculture. Eds. K Mulongoy and R Merckx. pp. 143-154. John Wiley \& Sons Ltd, Chichester, UK.

Vanlauwe B, Swift M J and Merckx R 1996 Soil litter dynamics and $\mathrm{N}$ use in a leucaena (Leucaena leucocephala Lam. (de Witt)) alley cropping system in Southwestern Nigeria. Soil Biol. and Biochem. 28(6), 739-749.

Vanlauwe B, Diels J, Duchateau L, Sanginga N and Merckx R 1998a Mineral N dynamics in bare and cropped Leucaena leucocephala and Dactyladenia barteri alley cropping systems after the addition of $15 \mathrm{~N}$-labelled leaf residues. Eur. J. Soil Sci. 49, 417-425.

Vanlauwe B, Sanginga N and Merckx R 1998b Recovery of Leucaena and Dactyladenia residue nitrogen-15 in alley cropping systems. Soil Sci. Soc. Am. J. 62, 454 460.

Vanlauwe B, Wendt J and Diels J 2001a Combined application of organic matter and fertilizer. In Sustaining Soil Fertility in West-Africa. Eds. Tian G, Ishida F and Keatinge $\mathbf{J}$ D H. pp. 247-280. SSSA, ASA, Madison, USA.

Vanlauwe B, Aihou K, Aman S, Iwuafor E N O, Tossah B K, Diels J, Sanginga N, Merckx R and Deckers S 2001b Maize yield as affected by organic inputs and urea in the West-African moist savanna. Agron. J. 93, 1191-1199.

Vanlauwe B, Aihou K, Tossah B, Diels J, Sanginga N and Merckx R 2004 Senna siamea trees recycle Ca from a Carich subsoil and increase the topsoil $\mathrm{pH}$ in agroforestry systems in the West African derived savanna zone. Plant and Soil 269, 285-296.

Section editor: P.J. Gregory 